\title{
ФОРМУВАННЯ СОЦІАЛЬНОГО ІНТЕЛЕКТУ У ШКОЛРІВ ПОЧАТКОВОЇ ШКОЛИ
}

\author{
Коровіна Я. С. \\ асистент вчителя, К3 «Солоницівський ліцей №2» Солоницівської селищної \\ ради Харківської області, здобувачка другого (магістерського) рівня вищої \\ освіти кафедри початкової та професійної освіти, Харківський \\ національний педагогічний університет імені Г. С. Сковороди, \\ м. Харків, Україна
}

У статті розглянуто прагнення школярів початкової школи до соціальної комунікації, взаємодії з однолітками й іншими суб'єктами освітнього процесу. Активізовано поведінкові знання про взаємодію і контакт з іншими людьми, вміння будувати дружні стосунки в колективі. Уточнено педагогічні умови формування у школярів початкової школи сочіального інтелекту.

Ключові слова: сочіальна комунікація, школярі, початкова школа, мисленнєва діяльність.

The article examines the desire of primary school students to social communication, interaction with peers and other actors in the educational process. Behavioral knowledge about interaction and contact with other people, the ability to build friendly relations in the team are activated. The pedagogical conditions for the formation of social intelligence in primary school students have been clarified.

Key words: social communication, schoolchildren, primary school, mental activity.

У суспільстві й освітянському просторі постійно відбуваються зміни, що стосуються особистості, їі призначення й самореалізації в різних сферах діяльності. Нині слід говорити про необхідність формування соціальної та громадянської компетентності особистості, що $є$ однією з ключових позицій Нової української школи. Потрібно це для побудови цивілізованої країни, в якій вільно й спокійно людина може не лише існувати, але й творити й духовно зростати. Кожен 3 нас воліє жити й працювати в соціально забезпеченому суспільстві, бути самодостатньою людиною, розкривати власний потенціал. Соціальна та громадянська компетентність у визначенні матеріалів Нової української школи являю собою вміння працювати в іншими людьми, співпрацювати на користь усіх і себе в тому числі, попереджувати 
й розв’язувати конфліктні ситуації, досягати компромісів, поважати закони й дотримуватися прав людини в умовах соціокультурного різноманіття. Такі вміння, як на нашу думку, слід формувати 3 дитинства, оскільки вони переходять у навички та конструктивну поведінку людини в громадському життя, в сім’ї, на роботі.

За основу наших думок прийнято наукові праці вчених, котрі досліджували дотичні до теми дослідження такі питання, як-от:

- розвиток соціального інтелекту майбутнього фахівця у процесі професійної підготовки (С. Карсканова);

- підготовка майбутніх учителів початкової школи до формування соціальної компетентності молодших школярів (О. Юрченко);

- розвиток соціального інтелекту учнів початкової школи (В. Стасюк, Ю. Фартушна).

Метою статті - розкрити питання формування у школярів початкової школи соціального інтелекту в науковій літературі.

Як свідчить аналіз наукової літератури [1-4], соціальний інтелект $€$ особистісним новоутворенням, котре можна уявити як прагнення школярів початкової школи до соціальної комунікації, взаємодії з однолітками й іншими суб'єктами освітнього процесу, поведінкові знання про взаємодію і контакт з іншими людьми, вміння будувати дружні стосунки в колективі. Подібним, але нетотожним є розуміння дослідниками В. Стасюк і Ю. Фартушної суті соціального інтелекту людини як сфери суб'єкт-суб'єктного пізнання, котре базується на механізмах розумових процесів та соціального досвіду, а також як здатність пізнавати й розуміти себе та інших людей, розкривати внутрішній потенціал засобами соціальної комунікації. На відміну вище сказаного, вчена О. Юрченко тлумачить поняття «готовність майбутнього вчителя початкової школи до формування соціальної компетентності молодших школярів» як особистісне новоутворення, компонентами якого є мотиви професійної діяльності, знання про соціальний інтелект, практичні уміння і навички допомагати соціалізації молодших школярів, їхньому становленню як громадянина, професіонала, сім'янина в майбутньому. Безумовно, кожен науковий підхід має право на існування, але в кожному з них бракує знань і вмінь працювати над собою, вдосконалювати свої здібності, рухатися до нових вершин. У нашому розумінні соціальний інтелект $є$ усвідомленням людиною свого призначення й місії в суспільстві, розумінням 
ролі соціальної комунікації в процесах самореалізації й саморозвитку особистості.

Нам імпонує структура соціального інтелекту молодших школярів [1], яка представлена у вигляді компонентів, а саме: 1) когнітивний; 2) поведінковий; 3 ) регулятивний. Заслуговує схвалення те, що автори уточнюють показники соціального інтелекту, як-от: соціальна адаптованість, відповідальність, емоційна стійкість, самоактуалізація тощо. Ми схильні додати до показників соціального інтелекту вміння мисленнєвої діяльності людини (аналізувати, порівнювати, узагальнювати, робити висновки).

Означимо педагогічні умови формування у школярів початкової школи соціального інтелекту, як-от: орієнтування мотиваційно-емоційної сфери молодших школярів на виявлення потреб у соціальній комунікації; розвиток соціального інтелекту школярів початкової школи шляхом запровадження активних методів виховання й навчання.

Отже, в науковій літературі існують різні підходи до тлумачення поняття «соціальний інтелект», що означає небайдужість науковців і практиків до проблеми формування соціального інтелекту людей різного віку.

\section{Список використаних джерел:}

1. Стасюк В., Фартушна Ю. Розвиток соціального інтелекту учнів початкової школи. http://www.wayscience.com/wp-content/uploads/2020/02/TOM3-Zbirnik-1-mizhnarodna-nauk-prakt-int.-konf-Winter-Debates.pdf\#page $=355$

2. Розвиток соціального інтелекту учнів початкової школи https://www. uzhnu.edu.ua/uk/infocentre/get/24165

3. Юрченко О.В.Підготовка майбутніх учителів початкової школи до формування соціальної компетентності молодших школярів : дис. ... канд. пед. наук: 13.00.0. Умань, 2018. С. 2-4.

4. Карсканова С. В. Розвиток соціального інтелекту майбутнього фахівця у процесі професійної підготовки. Педагогічні науки. Вип. 1.45 (106).

C. 59-63. http://mdu.edu.ua/wp-content/uploads/files/16_8.pdf 